\title{
Pedagogical and psychological conditions of preparing students for social relations on the basis of the development of critical thinking
}

\section{Akramova Gulbahor Renatovna}

Bukhara State University, dotsent of the Department Theory of Primary Education, Candidate of Pedagogical sciences https://orcid.org/0000-0002-2100-3222; gulbahor75@rambler.ru

\section{Akramova Surayo Renatovna}

Teacher of the Department of Theory of Primary Education, Bukhara State University, https://orcid.org/0000-0003-4115-6493

\section{ABSTRACT}

The following article deals with the ways of developing critical thinking in students, and their pedagogical and psychological conditions. Also there have been analyzed the stages and approaches of this issue.

Keywords:

critical thinking, thinking, criticism, critical thinking of the social educator, communicative literacy.

Article Received: 18 October 2020, Revised: 3 November 2020, Accepted: 24 December 2020

\section{Introduction}

The development of critical thinking in students is the basis for their development in society as professionals who own the skills of enterprising, inquisitive, creative, and able to correctly assess their behavior, have their own ideas, views, build and raise the foundation of our great future. Of course, the educational process is important in this field.

In order to implement the continuity and consistency of the content of education between the types of continuing education in the country, new State Educational Standards and curricula are being developed on the basis of a competency approach. It defines the parameters, criteria and requirements for the formation of students' independent, creative, critical thinking skills, scientific outlook, ability to interact with others and the correct assessment of events, to find their place in social life, also substantiates the current pedagogical problem too.

Therefore, in the educational process it is necessary to develop advanced pedagogical technologies that encourage active, independent students with critical thinking. In order to become active members of a strong democratic civil society for youth, it is necessary constantly develop their knowledge, skills and abilities. To do this, it is important for students to be creative, inquisitive, strong-willed, and industrious, to form beliefs, critically analyze the events around them, to take a worthy place in the micro-society in the future, to act as active members of society.

Scientific and theoretical sources on Pedagogy, Psychology, Philosophy, Sociology, textbooks on research, study, observation, analysis of pedagogical practice, the creation of a mechanism for organizing the educational process to prepare students for social relations based on the development of critical thinking, Methodological tools are used in this process, and shows the need to develop methods, techniques, technologies and strategies.

\section{The aim of the study}

Develop a methodology for preparing students for social relations based on the development of critical thinking in the process of general secondary education and the creation of scientific recommendations aimed at the use of this method in educational practice.

\section{Literature review}

An analysis of the psychological, pedagogical, and philosophical literature shows 
that the problem of developing critical thinking from the point of view of modern science is a very topical issue, but it is not sufficiently developed. By definition, "critical thinking" is primarily a form of thinking that has a specific, critical orientation, so we have defined its specific sequence of basic concepts as follows: thinking $\rightarrow$ criticism $\rightarrow$ critical thinking $\rightarrow$ critical thinking of the social educator.

Thinking in Psychology is one of the most studied categories, and its content acquires a specific character within the research topic. Psychologists belonging to different psychological fields to this phenomenon: associates (A. Ben, T. Gobbs, D. Gartley, E. Darwin, D. Mill, D. S. Mill, D. Priestley, G. Spencer, M. M. Troitsky and others); representatives of the Wurzburg school (A, K. Buhler, O. Kulpe, K. Marber, I. Ort, D. Watt, and others); behaviorists (E. Gazley, B. Skiner, E. Thorndike, J. Watson, K. Hull, and others.); cognitivists (P. Lindsey, D. Norman, A. Newell, G. A. Simon, R. Solso, D. S. Shaw, and others) gave different descriptions.

As a result of analytical analysis (B. G. Ananev, A. V. Brushlinsky, L. S. Vygotsky, P. Ya. Galperin, A. N. Leontev, S. L. Rubinstein, D. B.Elkonin) we have analyzed the concept of "contemplation" is a lifelong ability to perceive existence to solve various tasks, and to identify hidden things directly. In the science of modern Psychology, the category of "thinking" is broad internal process aimed at active perception of existence, management and planning of the external world) and narrow (process of solving various tasks and problems (I. M. Kondakov, A. A. Krylov, B. G. Meshcheryakov, V. P. Zinchenko, A. V. Petrovsky, V. M. Pokrovsky, G. F. Korotko studied in their researches).

Most psychological studies give similar definitions of the concepts of 'thinking' and 'intellect', though, but not exactly. According to the results of the theoretical analysis, if the concepts of "thinking" and "intellect" are compared, it becomes clear that the intellect is recognized as a concept that combines individual cognitive and creative abilities. Contemplation, in turn, summarizes an individual's intellectual ability in solving various problems and tasks. Hence, the process of thinking of the individual and its outcome is directly related to the intellectual capacity and as a result of the increase in the quality of cognitive and creative abilities, the intellect grows and develops. That is, the development of thinking means the growth and improvement of the intellect at the same time.

Psychology studies "thinking" as a mental process, while pedagogy studies the individual's ability to comprehend, learn, and focus directly on its formation. Analysis of pedagogical research on the formation and development of thinking (its basis was developed by F. A. Disterveg, I. G. Pestalotstsi, J. J. Russo, and later further developed through the theory of problem-based learning) studied as a method of solution, developed ways and means of formation and development of professionally oriented thinking in students in the process of training divisive specialists (V. P. Andronov, A. F. Bilibina, S. A. Gerasimov, V. K. Drachev, B. P . Esipov, N. Ya. Klepach, T. V. Kudryavtsev, V. A. Medvedev, E. K. Osipova, V. A. Slastenin and others). In Pedagogy, special attention is paid to improving the level of social adaptation, assessment of various phenomena, solving problems and tasks, the acquisition of new knowledge, the composition and development of various forms of thinking (M. G. Ageeva, T. A. Badanova, D. V. Bragina, N. E. Vysochkina, S. I. Gilmashina, E. V. Dozmorova, Kazakova, N. V. Kalyagina, O. V. Plotnikova, T. A. Polyakova, I. A. Sychev and others).

In modern Pedagogy, "thinking" is often described as "an indirect reflection of the external world based on impressions from reality" and a process that allows a person to use the necessary information, build their own ethical programs and plans based on their knowledge, skills and abilities (Pedagogical encyclopedia, dictionary).

In the process of reviewing the literature on the subject, we have witnessed the widespread use 
of the term "mental development" and "mental education" in pedagogy, as well as the term "thinking". Of course, although these two concepts are close to each other, there are some differences between them. "Mental education" is a process aimed directly at the subject of education; "mental development" is the process of changing it by educating the subject. At the same time, mental education determines and adapts to most mental development, but for this it is necessary to take into account the possibilities and laws of mental development of the subject through pedagogical influence. Therefore, in Pedagogy, great attention is paid to the study of the features of ontogeny of the individual.

By analyzing the concept of thinking as a philosophical, pedagogical and psychological category, we study this phenomenon as an active process of knowing the world through concepts, reasoning, scientific theory, hypotheses characterized by certain existing structures and laws of development and practice.

An analysis of the concept of "criticism" has shown that it is used in two main senses: negative, negative attitude, and in the sense of expressing an opinion based on evidence about something. Noting that the concept of "criticism" is used as a basic concept in the process of thinking and refers to the concept of direct analysis and conclusions, we use the concept of criticism in a broad sense and interpret it as an analysis of the outcome, legitimacy, essence of events with the aim of objective reflection.

Although there are those who believe that the term "critical thinking" originated in the field of formal logic, it should be noted that critical thinking is primarily practical in nature, so it provides insights into the individual characteristics of the subject under discussion. The analyst is interpreted as a specific form of practical logic (G. V. Sorina). At the same time, one of the most important features of critical thinking is that with its help the individual learns to analyze, express his opinion objectively, based on evidence and conclusions, professional knowledge, reflect on his own way of thinking, behavioral stereotypes, correct mistakes when necessary.

There are two different approaches to thinking about the nature of critical thinking in the modern psychological and pedagogical literature. One of them, based on the philosophical traditions of interpretation of reflection, studies the composition, structure and types of reflection as a psychological mechanism of self-reflection (N. B. Berezanskaya, J. J. Gilford, D. Halpern and others). The second approach examines the formation and development of productive and creative thinking skills in pupils and students as a basis (Y. N. Kulyutkin, O. K. Tikhomirov, I. N. Semenov and others).

Based on the descriptions given by different researchers to critical thinking, it can be noted that their most important aspects are organization, rationality, purposefulness, reflexivity, analytics and logic. A comprehensive review of these analytical descriptions has been explored by substantiating the social educator's critical thinking aimed at solving student-related problems under his or her care.

\section{Research Methodology}

The comprehensively created conditions and opportunities provided for the process of critical thinking of students create many benefits in the field of Pedagogy and Psychology. It is known that in Pedagogy and Psychology, the concept of mastery is used in addition to teaching and learning. All processes in secondary schools are done to achieve the same understanding. Therefore, in ensuring the quality of the educational process, in particular, the establishment of free thinking activities of the student determines the following pedagogical and psychological basis:

1. The process of students' perception of events in educational materials. In this process, specific interpretations are reflected, and the reader begins to perceive, that is, to understand, the existing situations. This interprets the first 
basis of the student's free thinking in the educational process.

2. Imagination based on the student's current situation. In doing so, the reader has a clear idea of the state of both the past and the future through the present state of any aspect, based on the information available to him, based on the available information.

3. His observation of the process is another basis for his subsequent actions. He learns to break down any whole object into parts or to compare objects in order to set a clear and definite goal for himself. This shows its impact on his work. Therefore, in the free thinking of the student, his observation with observation develops.

4. Another pedagogical-psychological basis of free thinking is to understand something. Through understanding the reader understands the interconnectedness, the connection, in the environment and society among people. It simply withdraws from thinking and seeks an opportunity to comprehensively clarify internal, external connections, cause and effect relationships.

5 . Inference is a process in which a certain conclusion is reached on the student's free thinking. In particular, the student tries to draw conclusions as a result of his understanding of the information. Any conclusion requires justification. The student is already interpreted as a pedagogical-psychological basis for drawing conclusions.

6. The process of memorizing learning materials and materials needed for critical thinking. Comparison with this aspect of free thinking in any situation provides a basis for analysis. This in turn is a necessary opportunity for the psychological impact of the student.

7. Another aspect of directing the student to think freely is to be able to engage the student. The student tries to think freely based on curiosity, explores, and strives to achieve something.

In the process of teaching and social life, the formation of free thinking in students, increasing their interest in developing their potential has a special role in education. Therefore, from the first years of independence of Uzbekistan, the issue of giving freedom to students, creating opportunities for them to work independently was recognized as an urgent issue. After all, free thinking is an important factor in shaping a harmoniously developed generation. In order to classify, analyze and supplement the content of the work done, it will be necessary to compile the following:

- Development of students' conscious attitude to the educational process;

- The formation of theoretical knowledge, practical skills and abilities in students;

- To be able to identify and direct students' talents, abilities and talents for their development;

- Systematization of views on changes in economic, social and political life;

-Increasing the responsibility of participation in events in society.

The ongoing development, the news puts a number of pedagogical and psychological tasks in directing the reader to critical thinking. In order for a student to think freely, he or she must first have a need. Without it, the reader will not think. In any case, if the reader feels the need for critical thinking spiritually, he learns, searches, moves. Students should be able to clearly see the intended purpose for critical thinking in any direction to develop critical thinking potential. In some cases, the situation that has arisen for students to think critically is that there is no definite conclusion about the situation, no results have been achieved.

The wealth of a state, a nation depends in many ways on the human factor, its intellectual potential, the level of critical thinking. After all, critical thinking is achieved by activating people through capacity building.

It should be noted that the different approaches in the educational process are applied in practice, taking into account the available opportunities, and in this case it is important to achieve the goal in different ways. In particular, for many years we have been using the method of reproductive, that is, retelling, narration teaching 
in school. The textbooks and programs were designed for this, and the teachers were also accustomed to asking and listening over and over again what was given in the textbook. The period demands a new one: now the reader must show his opinion, the product of his research, not what is written in the book, should be able to use the opportunities of the educational process to demonstrate the ability to express them correctly and fluently. Such skills and competencies in the student can be formed and developed only on the basis of his continuous independent research in the classroom. In the educational process students' learning activities are structured as follows:
1) Tracking;
2) Research;
3) Interpretation of differences;
4) Comparison;
5) Interpretation of generality;
6) Interpretation of differences;
7) Classification;
8) Judgment;
9) Identification of relevance;
10) Application.

Each new topic definitely gives the reader new knowledge of certain type and level. The new knowledge imparted should serve to open up the possibilities of the reader, to enrich the written and oral speech, to expand the scope of thinking. The main difference between the teaching of social sciences and humanities is that in many subjects the student learns the basic concepts only in school, and in the social sciences the events deepen and expand the skills and abilities of the student to get acquainted with the events.

Comparison with the similar meanings of the studied phenomenon (synonyms, functions, forms, contradictions, etc.), the activity of determining their relationship with them:

a) To determine the degree to which the student has read the verdict on the incident;

b) To teach him that there are different means of expressing the same essence in language, and thus to expand the possibilities of language; c) To emphasize the difference between events that are essentially close.

This process is gradually becoming more complicated. For example, if history lessons compare the events of different periods and emphasize the main differences between them, the idea of national independence and the fundamentals of spirituality are different names of national ideology, in general, it is the understanding of national identity and devotion to their people and country.

Different expressions are also compared and students 'knowledge is both deepened and strengthened.

The activity of applying the phenomenon learned by the student in the process of learning is the main purpose of the study of the topic and is to develop a certain type of skill and competence in the student. Applied activity occurs as a result of thinking, in the form of large or small, written or oral texts, and emerges in different forms according to the nature of the event. For example, if one can take the form of independent research or creativity in creative work on various topics, one can take various forms of independent creative work in economics, including changes in market economies, stages of development, their place and importance in our lives, and market relations.

Critical thinking requires the organization of education in such a way that, on the one hand, it focuses on the formation of a creative personality, on the other hand the uniqueness of each young person's individuality, taking into account his own will and life aspirations. The student must be a critical subject of school life, the educational process of learning, all types of activities (art, labor, education, sports, social organization). Only in this case, pedagogical thought will always be focused on students, their age and individual mental and physical characteristics and abilities, the search for ways and means of developing them in accordance with the social norms of upbringing and education. 
It is aimed at cultivating in students such personal qualities as teamwork and brotherhood, friendship, diligence and inquisitiveness, where initiative and independence are combined.

Harmonious upbringing involves the continuous implementation by students of all the basic types of conscious activities of people play, labor, art, education, sports, and social organization. In this case, the initial form of any activity is its collective performance, which over time becomes individualized. Of course, the harmony and level of the types of activities listed at each age are different, but their combined manifestation provides a complete moral, mental, artistic and physical education. It is in the collective form of activity that the effective acquisition of knowledge, learning and skills by a person takes place.

In traditional Pedagogy it is well known that teaching takes precedence, which leads to overintellectualization, as a result of which technocratic thinking takes precedence, and technology takes precedence over human values.

One of the most important features of the new pedagogy is the approach to education as a state-social system. (Until recently, only the state approach was a priority). This approach involves the participation of social councils at different levels in the management of education, as well as the diversity of school types (like the possibility of having authorship careers).

The social order of education is to teach the student to think, to understand the opinion of others, and to be able to express the product of this thought orally and in writing, that is, to develop communicative literacy. Therefore, the goal of this education is to develop a student who is socially well-formed, able to think critically, and has a well-developed culture of speech and communication.

For this purpose, the content of education should include:

- To develop the student's thinking ability, mental development, logical thinking;

- To focus on solving students' problems of self-awareness, material existence, and the ability to express their thoughts and feelings within the broad possibilities of education.

The main task in education is to form students' critical thinking.

Curriculum development takes into account, first and foremost, the overall development of students as they work on the text.

Here the followings have been considered:

A) Students' perception of the surrounding subject phenomena and their diversity;

B) The ability to correctly distinguish between the causes, conditions, contradictory relations between these subject-events;

C) The ability to express their feelings in words and communicate their knowledge to others.

Thus, a student with a high level of general development is also distinguished by critical thinking and the ability to express their thoughts orally and in writing.

If students' critical thinking skills and competencies develop, they will be able to quickly understand and analyze similarities or differences between words, regardless of the exact meaning of the words and phrases, depending on the forms, the means by which the words interact.

The state educational standard of general secondary education determines the content, forms, means, methods of education, the procedure for assessing its quality. In addition to ways to develop students' mental activity in the learning process, there are also ways to form their creative thinking.

It is known that lessons in this area are one of the main tools for shaping a socially active person. The lesson is a two-way process in which both the teacher and the student are actively involved. Therefore, not only the teacher's activity, but also the student's activity should be the basis for the use of teaching methods. From this point of view, it can be observed that there are teaching methods related to teacher and student activities:

1. Methods related to teaching. 
2. Methods related to student activities.

Methods related to teacher performance can be divided into three types. They are:

\section{Method of description}

This method is widely used in the educational process. This method is used to explain the essence of any definition, to provide additional information in order to fill in the gaps in students' knowledge, and to answer their questions.

\section{Conversation method}

This method plays an important role in developing students 'critical thinking skills. Therefore, the development of critical thinking in students is characterized by the breadth of opportunities of the social sciences and humanities. By being able to apply this method in any teaching process, a positive environment between the student and the teacher will find content. The interview method is based on wellthought-out questions and assignments with an effective outcome.

\section{The method of problem statement}

Students' critical thinking skills are formed by creating problem situations in the classroom. Students are able to find different ways to get out of situations, to find solutions to problems, to demonstrate all their existing abilities and capabilities through decision-making processes.

By explaining the problem to students in different ways, it poses a certain problem to the students by using logical-linguistic factors such as observation, comparison, identification of similarities and differences, generalization.

The problem-solving method also serves to shape students 'creative thinking. Because students are explored in all of these processes, and in the process of research, they are directed to creative thinking based on their existing experience and knowledge.
Methods related to teacher activity take into account the creation of problem situations and the activity of students in the research-based study of language materials in these areas.

The development of students' thinking activities is central to the lessons in the field of education. This is an important factor in enhancing students 'learning activities. There are ways to organize student activities in the process of independent acquisition of knowledge by students and the transformation of this knowledge into skills and competencies. There are methods that are used in the process of students' independent learning and serve to shape their creative thinking. They are:

1. Reproductive (recovery) methods.

2. Partial search methods.

3. Research-based methods.

Each of these methods influences the formation of students 'critical thinking in the lessons of the learning process.

It is not only the learning process; the family environment in the upbringing of students in the implementation of these methods is unique as well. After all, from the moment a child is born, he or she lives in a family environment, and family-specific traditions, values, and customs nurture him or her. From this period onwards, forming the children critical thinking imposes a great responsibility on family members, teachers and educators.

One of the popular methodological methods that are considered to be very useful in terms of shaping critical thinking is the Task-Analysis method. TASK is an acronym for (Thesis Analysis - Synthesis - Key). Its usefulness for students and teaches them to think without distracting from certain aspects of the text. This method consists of 10 questions in a sequential sequence, to which students must find the answer by reading the text. Writing answers have specially designed table and it is relatively efficient. 


\begin{tabular}{|l|l|}
\hline Question & Answer \\
\hline 1. What subject is being discussed? & \\
\hline 2. What is the main notion of the theme? & \\
\hline 3. Form an opinion: What comments do you think the opponent \\
will make to defend his / her opinion?
\end{tabular}

Thus, the proposed method forces students to approach the text as both a reader and a coauthor, and teaches them to read the text and work together to produce evidence. As long as the student is able to evaluate the evidence presented by the author and suggest additional ideas, his collaboration with the author is considered established. In addition, TASK teaches the reader to be critical at the same time, while being positive about the values and opinions expressed by the author. Using TASK significantly increases students' ability to assess what they read. These include the weaknesses of their arguments in preparation for group debates, including the inadequacy of the material chosen for the argument, the inability to present sufficient evidence to defend their point of view, the erroneousness of their beliefs, and the fact that they belong to an influential person. In this way, they learn to organize the evidence rationally.

If students are able to work on the text individually using the textbooks, they can use the text as a graphic to summarize the necessary parts.

Forms of such marking include: underlining the relevant parts of the text, highlighting with colors, marking with certain symbols, and others. Experts in the field of working with the text have created two types of methods, one of which has its own name and description, one of which is the "Insert" method. INSERT is an English acronym (INSERT - Interactive Noting System for Effective Reading and Thinking) which literally means "an interactive system of writing for effective reading and thinking". 
This method is implemented in several stages.

Step 1: Students are encouraged to use the following marking system to properly distinguish ten pieces of information as they study the text:

(V) mark the information they already know with the "bird" sign;

(-) The "minus" sign distinguishes things that are contrary to their imagination;

(+) Use the "plus" sign to indicate information that they consider extremely interesting;
(?) Mark the information they do not understand enough and want to know more through the question mark.

Step 2: While reading the text, students mark the appropriate paragraph and box (border). When reading and marking the text in the classroom, the tutor (lecturer) can give relevant comments during the reading.

Step 3: Students are encouraged to organize the information according to the following table:

\begin{tabular}{|l|l|l|l|}
\hline $\mathrm{V}$ & + & -- & $?$ \\
\hline & & & \\
& & & \\
\hline
\end{tabular}

Step 4: Consistently analyze the data in each graph of the table.

The insert method should be used in the analysis of texts rich in solid evidence and information. This method helps to develop analytical thinking in students and is a tool for understanding the material. The INSERT stages correspond to the three-stage model of "Callingthinking-reflection" to organize the learning process.

The suggested symbols can be replaced with other symbols depending on the request. For example: "!" can be used instead of "+". The important thing is to use the criteria for accurate ranking of information.

One of the most convenient methods to use is the "Plus, minus, interesting" method. In this method, the text is marked with three types of symbols - the logic of marking is determined by the tutor or the students themselves. For example, text analysis can be done from the point of view of a thesis. In this case, the "plus" sign is used to denote the evidence aimed at a strong interpretation of the thesis, while the "minus" sign is used to indicate some weak information or the argument used to confirm the idea or data contrary to the thesis. These 3 signs can also be used by the reader to assess the relevance and novelty of the material.

Here is another way of thinking about the text.

Essay (French "Essai", English "essay" or "assay" - experience, essay, lot. "Exagium" - to lift up) is a free description of any critical journalistic, social, moral, aesthetic, and philosophical problems. The essay is usually presented in a free descriptive manner, as opposed to the systematic scientific approach used to describe the issue. Essays are one of the most widespread genres of writing in Western pedagogy, and this form and term have become quite common in Russian schools in recent years. An essay can be used to reinforce the material being read by using less written material at the stage of thinking in the study of the text.

There are many scientific and popular treatises on essay writing. It should be noted that the different types of essays are determined by the following factors:

- According to the time spent on it; 
- According to the ability to create logical compositions (for example, call, statement of the thesis, proof, conclusion);

- The ability of the author to use the artistic potential, expressive speech, artistic and valuable context.

Essay writing is a serious activity that takes 5-10 minutes of free time. For the student, the essay is one of the most interesting creative activities for working on the text, while for the tutor; the essay is an important diagnostic tool for identifying the student's knowledge, skills and abilities in the learning process.

We often think of critical thinking as a way of thinking on a daily basis. As we seek answers to the question of what critical thinking is, we inevitably come across a number of statements, such as "check carefully, approach everyone carefully," "practice logic," and "re-examine the data". All of this is good, but HUMAN is not able to think critically without knowing what critical thinking is. Similarly, it is not possible to use a computer effectively enough without knowing its capabilities and functions.

Critical thinking is not an innate ability, but it is necessary for every person to shape it throughout life. This is why it is important that the ability to think critically allows a person to express himself, not to dominate himself, to teach clear thinking, orderly reception of information and data.

How to develop the ability to think critically, where to start? The starting point for training is meta-cognitive. In order not to bother you with complex scientific terms, it is easy to say that this term means that a person has a deeper and broader knowledge of his own thought processes or knowledge. How can this be achieved? We can say through self-awareness, external observation, analysis and evaluation of one's own decisions. Before going to sleep, he should think about how his actions, thoughts, feelings, and the logic of his thoughts and reflections are expressed during the day. Their benefits and harms can be assessed in the same way (no decision can be made in vain).

It is obvious that this ability is developed with the help of memory. Our memory is not an exact copy of what happened. What we remember is influenced by our knowledge, stereotypes, and the content of the material. In this way, less memorized meta-words are useless. Memory gives you the materials you need to work on yourself, allows you to examine existing data and information, and compare them with your own experience.

Anyone who wants to form a critical mind is required to show two things: to examine the consequences of the conclusions drawn from the presumptive judgments and to prove the reasoning. In the first case, we can talk about the immutability of our judgments (the beginning of contemplation) as we meditate. In other words, concepts may not be replaced, but may change with our feelings and circumstances. In order for our opinion to have evidence, the following rules must be observed:

1) The judgments must not contradict each other;

2) Our judgments should be sufficiently linked to our conclusions and affirmed;

3) Components of other evidence (contradictory opinions, dissenting evidence) should be taken into account in our consideration.

You don't have to worry about books full of logical assignments to approve or reject hypotheses. Life itself gives you the opportunity to do this, and even in everyday life you have to check it to believe in the hypothesis. As we form our perceptions of the universe, we observe and gather evidence, which allows us to acquire active knowledge. But when we think of clearer truths (such as the possibility of pouring boiling water), of course, we forget the critical approach. The same approach to our belief in television news and gossip, that is, our blind faith, leads us to draw the opposite conclusions, not to draw conclusions based on examples. Everyone has experienced such a "trap". Therefore, be sure to check any 
information, no matter how reliable it is, from a reliable source.

Examine the evidence. In fact, the reason we are skeptical of anything is simply a simple requirement, such as examining the evidence. To do this, you can use the following algorithms:

Avoid selected evidence. You cannot acquire true knowledge just by gathering evidence to support your hypothesis. The reason is that the connections must be made in full. What did you know in advance? Is this information sufficient to confirm your hypothesis? In doing so, you need to be truthful about yourself, and not just rely on existing knowledge and evidence that will be confirmed by others, but also study the views and evidence that contradict it.

Use all available tools. If necessary, use the evidence you have obtained from the sources, as your information may be someone's conclusion and it may be wrong to accept it as true.

-Accuracy is the last requirement for the formed conclusion. Can you reduce uncertainty? Are the conclusions of good quality or are there still weak points? It is not possible to draw valid conclusions without answering these questions.

-Make wise decisions above, we thought about the decision-making process and how to avoid common mistakes.

-Formulate tasks in a variety of ways. This will allow you to see different aspects of the problem.

-Think of even the most insidious and irrational scenarios. People have a strange tendency not to be able to see the negative aspects, so it is necessary to take them into account in order to know what to do when not everyone is happy.

-Once you've come up with something out of the ordinary, then work from the bottom of the list eliminating issues that aren't worth the fight.

\section{Task structuring.}

The process of solving tasks takes place in 4 stages: preparation and acquaintance, decisionmaking, decision-making, evaluation of its effectiveness. This simple sequence teaches you to structure your mind and think more effectively.

\section{Develop creativity.}

"Psychology of critical thinking" is studied as a "cognitive process of creativity" that is stored in the memory and comes out of the shell of personal experience. It is creativity that teaches you to look at a problem from different angles, to use ideas to solve it, and to solve them, unlike other people who are not creative.

Today's students need to approach the educational process while creating the pedagogical and psychological basis for the current state of critical thinking, because it prepares the student for the process, both pedagogically and psychologically, and develops the ability to think critically. This shows that the theoretical and practical basis for the development of critical thinking skills.

\section{Conclusion and recommendations}

In conclusion, it can be said that the pedagogical and psychological basis of the current state of critical thinking activities of students is aimed at:

1. Incorporate into the content of educational and normative documents issues related to the formation of critical thinking of students;

2. To systematize the work related to the organization of independent activity of the student;

3. To increase the effectiveness of the environment in the correct organization of the psychological state of students;

4. To develop in students the ability to overcome any problems;

5. To educate students who can contribute to development and have the skills to conduct their own research.

In order to improve the quality of education in the educational process, it is necessary to create conditions for students, to pay special attention to the study of their interests and needs. Thus, the systematic approaches, the logical, substantive 
and substantive membership of the pedagogical and psychological bases are proved.

Through their learning activities, students' worldviews and thinking are formed, and their conscious attitude to the social system is formed.

It is known that in the process of learning, the student's activity increases and his interest in academic subjects is formed.

They work to achieve positive results in the educational process, first of all, to impart scientific knowledge to the younger generation, to teach them the basics, to form in them a broad outlook and scope of thinking, to form their spiritual and moral qualities. In itself, this effectiveness is inextricably linked with the organization, conduct and results of the teaching process in educational institutions. This process also plays a role in developing students' critical thinking skills. In particular, one of the main goals of the subject teaching process is to improve the quality of teaching content by developing students' critical thinking skills.

Nowadays, in the period of scientific and technical development, along with the development and personal needs, it is necessary to take into account the interests and intellectual potential of the student. It is a project of the process of formation of the student's personality, which can guarantee pedagogical success, it is necessary to effectively use the factors that allow the student's creative environment to express their views critically.

\section{References}

[1] Akramova Surayo

Renatovna. Interpretation of lexical and semantic features of uzbek-tajik words in jamal kamal's poem "Uzbek language. ACADEMICIA: An International Multidisciplinary Research Journal Year: 2020, Volume: 10, Issue: page:1434-1440. https://saarj.com/wpcontent/uploads/ACADEMICIAOCTOBER-2020-FULL-JOURNAL.pdf

[2] Akramova G. R. Modern approaches to the development of critical thinking of students. European Journal of Research and Reflection in Educational Sciences Vol. 7 No. 11, 2019 ISSN 2056-5852. http://www.idpublications.org/wpcontent/uploads/2019/09/Full-PaperMODERN-APPROACHES-TO-THEDEVELOPMENT-OF-CRITICALTHINKING-OF-STUDENTS.pdf

[3] Akramova G.R., Akramova S.R. Developing critical thinking on elementary class pupils is the most important factor for preparing social relationship. JOURNAL OF CRITICAL REVIEWS. ISSN- 2394-5125 VOL 7, ISSUE 17, 2020. URL: http://www.jcreview.com/?mno=20061

[4] Akramova G.R., Bakhshulloeva Sh.A. MOTIVATION AS A FACTOR IN THE SUCCESS OF EDUCATIONAL ACTIVITIES OF PRIMARY SCHOOL STUDENTS.

https://internationalconference.ru/images/PD F/2020/60/motivatsiya-kak-faktor-.pdf

[5] Akramova Gulbakhor Renatovna. Psychological and pedagogical foundations for the development of critical thinking of students. Academicia: An International Multidisciplinary Research Journal Year: 2020, Volume: Vol. 10, Issue 4. P.581-584. https://www.indianjournals.com/ijor.aspx?ta rget $=$ ijor: aca $\&$ volume $=10 \&$ issue $=4 \&$ article $=081$

[6] Gafurovna Lukmonova Salomat. The essence of the content of the concept of digital educational resources and its role in primary education. ACADEMICIA: An International Multidisciplinary Research Journal. 2020, Volume: 10, Issue: 5. P.1451$1456 . \quad$ https://saarj.com/wpcontent/uploads/ACADEMICIA-MAY2020-FULL-JOURNAL.pdf

[7] Pirniyazova Sholpan Oteniyazovna. THE SYSTEM OF DEVELOPMENT OF COMPETENCIES FOR THE CORRECTION OF THE EDUCATIONAL 
PROCESS IN STUDENTS OF HIGHER EDUCATION. JCR. 2020; 7(12): 30823088. doi:10.31838/jcr.07.12.466

[8] Polvonov Nurbek Omonboevich. SYSTEM FOR DEVELOPING SKILLS OF DIGITAL TECHNOLOGY IN TEACHING OF THE MODULE "ELECTRICATION OF MINING ENTERPRISES" TO THE STUDENTS. JCR. 2020; 7(12): 30893095. doi:10.31838/jcr.07.12.467

[9] Pulatova Odinahon Khamidovna. THE MECHANISM OF DEVELOPING A CULTURE OF COMMUNICATION IN STUDENTS IN THE EDUCATIONAL PROCESS. JCR. 2020; 7(12): 30963103. doi:10.31838/jcr.07.12.468

[10] Ruziyeva Mohichehra Yokubovna. About color symbols in folklore. JCR. 2020; 7(17): 461-466 \ Abstract » $\mathrm{PDF} »$ doi: 10.31838/jcr.07.17.64;

[11] Safarov Firuz Sulaymonovich, Istamova Shohida Maqsudovna. TYPES OF LEXICAL MEANINGS. Journal of Critical Reviews. 2020; 7(6): 481-484.

[12] Safarova Rohat Gaybullayevna. PEDAGOGICAL TOOLS THAT SERVE THE DEVELOPMENT OF CULTURAL VIEWS IN THE SUBJECTS OF THE EDUCATIONAL PROCESS. JCR. 2020; $7(12)$ : 31043108. doi:10.31838/jcr.07.12.469

[13] Saidova Nilufar Ruzimurotovna. USE FROM MEANS OF INFORMATION AND COMMUNICATION TECHNOLOGIES IN THE FORMATION OF MATHEMATICAL COMPETENCES OF PRIMARY CLASS PUPILS. JCR. 2020; 7(12): 31093114. doi:10.31838/jcr.07.12.470

[14] Samarova Shoxista Rabidjanovna, Rakhmonova Muqaddas Qahramanovna, Mirzarahimova Gulnora, Ikromovna, Maratov Temur Gayrat ugli, Kamilov Bobir Sultanovich. Psychological aspects of developing creative personality and the concept of reduction of creativity to intellect. JCR. 2020; 7(17): 498-505. doi: 10.31838/jcr.07.17.69

[15] Sharifzoda Sardorbek Urozboy Tabib Ugli. THE USE OF AN INTEGRATIVE APPROACH IN THE FORMATION OF BASIC COMPETENCIES IN STUDENTS AS A SOCIO-DIDACTIC NECESSITY. JCR. 2020; 7(12): 31153120. doi:10.31838/jcr.07.12.471

[16] Tilavova Matlab Mukhamadovna, Husenova Aziza Sharipovna, Hakimova Nargiza Supkhonovna. THE SYSTEM OF DEVELOPMENT OF PROFESSIONAL COMPETENCE IN FUTURE PRIMARY SCHOOL TEACHERS. JCR. 2020; 7(13): 4184-4189. doi:10.31838/jcr.07.13.635

[17] Tojiboeva Hilolaxon Makhmutovna. STRATEGIES FOR THE FORMATION AND DEVELOPMENT OF SKILLS STRUGGLING FOR "MASS CULTURE" IN THE SUBJECTS OF CONTINUING EDUCATION. JCR. 2020; 7(13): 41904195. doi:10.31838/jcr.07.13.636

[18] Turebekova Guljakhan Adilbekovna. TOOLS FOR DEVELOPING RESPONSIVENESS SKILLS IN PRIMARY SCHOOL STUDENTS. JCR. 2020; 7(12): 31273132. doi:10.31838/jcr.07.12.473

[19] Urinova Nilufar Muhammadjonovna, Tojiboeva Hilolakhon Makhmutovna, Maksudov Ulugbek Kurbonovich. IPROVING THE MECHANISM OF INCREASING THE SOCIAL ACTIVITY OF YOUNG PEOPLE IN THE DEVELOPMENT OF A DEMOCRATIC AND LEGAL SOCIETY. JCR. 2020; 7(12): 3133-3139. doi:10.31838/jcr.07.12.474

[20] Лукмонова С.Г. ЦИФРОВЫЕ ОБРАЗОВАТЕЛЬНЫЕ РЕСУРСЫ В ПЕДАГОГИЧЕСКОЙ ДЕЯТЕЛЬНОСТИ [DIGITAL EDUCATIONAL RESOURCES IN TEACHING] // XXI INTERNATIONAL SCIENTIFIC REVIEW OF THE PROBLEMS OF PHILOSOPHY, 


\section{PSYCHOLOGY AND PEDAGOGY.}

Boston, USA - 11 October, 2020.

https://scientific-

conference.com/h/sborniki/yuridicheskie-

nauki2/2249-media-security-trend.html 